\title{
MANUFACTURING THE TECHNOLOGY OF XENON-CONTAINING DRINKING WATER AND ITS INFLUENCE ON SOME PSYCHOPHYSIOLOGICAL CHARACTERISTICS OF MAN
}

Irina Verkhovskaya ${ }^{\mathrm{a}}$, Evgeny Petrov, Alexander Verkhovskiy

National Research Tomsk State University, 634050, Tomsk, Russia

\begin{abstract}
This study is aimed to describe the technology of making xenoncontaining drinking water and its impact on health and psychophysiological characteristics of 26 volunteers after regular admission. Testing conducted after 2 months of daily use such water showed significant improvement of emotional state and health of volunteers. This technology allows obtaining a large amount of drinking water saturated with xenon, which can be used in therapeutic and prophylactic purposes.
\end{abstract}

\section{Introduction}

The therapeutic capabilities of xenon are well known and have been used successfully [1, 2]. Mechanisms of action of xenon on the body associated with its effect on receptors [3-5] and the state of membranes [6-9]. Xenon is an amphiphilic substance, but its solubility in oils is 20 times higher than in water [10]. As a result xenon may accumulate in any hydrophobic structures, for example, in the middle of a cell membrane bilayers [11]. Therefore, it is expectable the impact of xenon on the vital organs, including the CNS. Now xenon is used in the form of inhalations, which results in decrease in fatigue, improve sleep, prevent the development of stress, and improve the adaptability of the organism [12]. Using our own technology of xenon dissolving in a variety of liquid funds and products, and with questionnaire test, we decided to see how overall psychophysiological profile of adult men may change after daily drinking water with xenon. Our results showed an improvement in psychosomatic characteristics that we associate with a regular intake of drinking water with xenon.

\footnotetext{
${ }^{a}$ Corresponding author: alverkhovniy@mail.ru
} 


\section{Materials and methods}

For effective administration of xenon to the drinking water, we have developed a technology using a high speed stirrer in a sealed vessel volume 101. Flowsheet is shown in Figure 1.

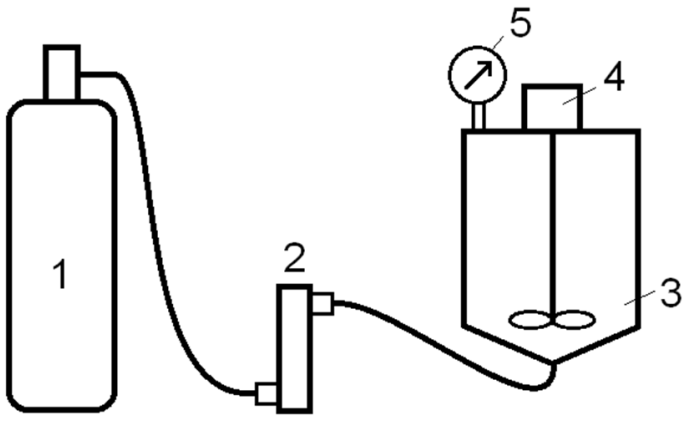

Figure 1. Block diagram of the apparatus for producing the xenon-containing drinking water: 1 - cylinder with xenon, 2 - flowmeter, 3 - water tank, 4 - high speed mixer, 5 - manometer.

The amount of dissolved xenon monitored by the change in pressure inside the container. Xenon (>99.999\%, Tianjin Dongchuangrixing Technology Co. Ltd, China) was fed through a $5 \mathrm{~mm}$ tube into water tank through the flowmeter. Xenon concentration measured by gas chromatography was 10.7 vol.\%. The work was done within two months in the summer time. The study involved 26 male workers aged 21-49 years on a voluntary basis after receiving an informed consent from each volunteer. All participants were given every day 3 bottles of drinking water saturated with xenon volume of $330 \mathrm{ml}$. Water with xenon prepared by our own technology. Xenon concentration in water was $10.7 \%$ (vol). To determine the concentration of xenon gas chromatography method used. To evaluate the psycho-physiological state is a questionnaire, which are commonly used in medical examination. To reply to a questionnaire proposed 3 options: None; Occasionally; Have / Noticed. The results were evaluated by comparing the responses to the questionnaire before and after 2 months of drinking daily water with xenon. The data were processed statistically (Microcal Origin, USA).

\section{Results and discussion}

Results of testing before and after 2 month of consuming xenon-saturated water are presented in Table 1.

Table 1. Results of testing.

\begin{tabular}{|c|c|c|c|c|c|c|}
\hline \multirow[t]{2}{*}{ Question } & \multicolumn{3}{|c|}{$\begin{array}{l}\text { Responses before } \\
\text { receiving water saturated } \\
\text { with xenon }\end{array}$} & \multicolumn{3}{|c|}{$\begin{array}{l}\text { Responses after receiving } \\
\text { water saturated with xenon }\end{array}$} \\
\hline & No & $\begin{array}{l}\text { Occas } \\
\text { ionall } \\
\mathrm{y}\end{array}$ & $\begin{array}{l}\text { Have / } \\
\text { Noticed }\end{array}$ & No & $\begin{array}{l}\text { Occasi } \\
\text { onally }\end{array}$ & $\begin{array}{l}\text { Have / } \\
\text { Noticed }\end{array}$ \\
\hline $\begin{array}{l}\text { Do you have headaches or } \\
\text { dizziness? }\end{array}$ & 9 & 7 & 10 & 17 & 5 & 4 \\
\hline Have you had faintings? & 20 & 6 & 0 & 22 & 4 & 0 \\
\hline Do you have digestive & 4 & 8(diar & 8 & 11 & 6(diarr & 4 \\
\hline
\end{tabular}




\begin{tabular}{|l|l|l|l|l|l|l|}
\hline $\begin{array}{l}\text { problems: bloating, } \\
\text { constipation, and diarrhea? }\end{array}$ & $\begin{array}{l}\text { rhea, } \\
\text { consti } \\
\text { pation } \\
\text { (constipa } \\
\text { tion) } \\
6\end{array}$ & $\begin{array}{l}\text { (diarrhea } \\
\text { (constipa }\end{array}$ & $\begin{array}{l}\text { hea, } \\
\text { constip } \\
\text { ation) }\end{array}$ & $\begin{array}{l}\text { (con) } \\
\text { tion } \\
\text { (diarrhea } \\
\text { (1) breathing }\end{array}$ \\
\hline $\begin{array}{l}\text { Do you have } \\
\text { difficulties: rapid breathing, } \\
\text { feeling short of breath? }\end{array}$ & 13 & 9 & 4 & 15 & 9 & 2 \\
\hline $\begin{array}{l}\text { Do you experience } \\
\text { palpitations, heart sinking? }\end{array}$ & 11 & 12 & 3 & 10 & 12 & 4 \\
\hline $\begin{array}{l}\text { Do you experience excessive } \\
\text { sweating? }\end{array}$ & 16 & 4 & 6 & 19 & 4 & 3 \\
\hline $\begin{array}{l}\text { Do you notice decreased } \\
\text { performance, increased } \\
\text { fatigue? }\end{array}$ & 9 & 6 & 9 & 19 & 3 & 5 \\
\hline $\begin{array}{l}\text { Do you have sleep } \\
\text { disorders? }\end{array}$ & 7 & 8 & 9 & 18 & 5 & 3 \\
\hline $\begin{array}{l}\text { Do you notice blurred } \\
\text { vision? }\end{array}$ & 20 & 3 & 3 & 20 & 3 & 3 \\
\hline $\begin{array}{l}\text { Do you notice a hearing loss, } \\
\text { ringing in the ears? }\end{array}$ & 15 & 7 & 4 & 22 & 3 & 1 \\
\hline $\begin{array}{l}\text { Do you have a sense of inner } \\
\text { tension or worrying? }\end{array}$ & 23 & 3 & 0 & 23 & 3 & 0 \\
\hline $\begin{array}{l}\text { Do you have disturbing } \\
\text { thoughts, anxiety, fear? }\end{array}$ & 16 & 6 & 4 & 17 & 4 & 5 \\
\hline $\begin{array}{l}\text { Do you look after your } \\
\text { appearance? }\end{array}$ & 19 & 2 & 5 & 15 & 2 & 7 \\
\hline $\begin{array}{l}\text { Do you fommunicating with friends, } \\
\text { comm } \\
\text { colleagues? }\end{array}$ & 7 & 4 & 15 & 4 & 3 & 19 \\
\hline
\end{tabular}

Analysis of the responses showed that after 2 months of daily drinking of xenoncontaining water the shift of subjective psychophysiological indicators take place. It was noticed a general decrease of anxiety and physiological disorders (Figure 2). Almost all workers (25 of 26) would like to continue to drink water with xenon because felt an improvement in their overall condition. 

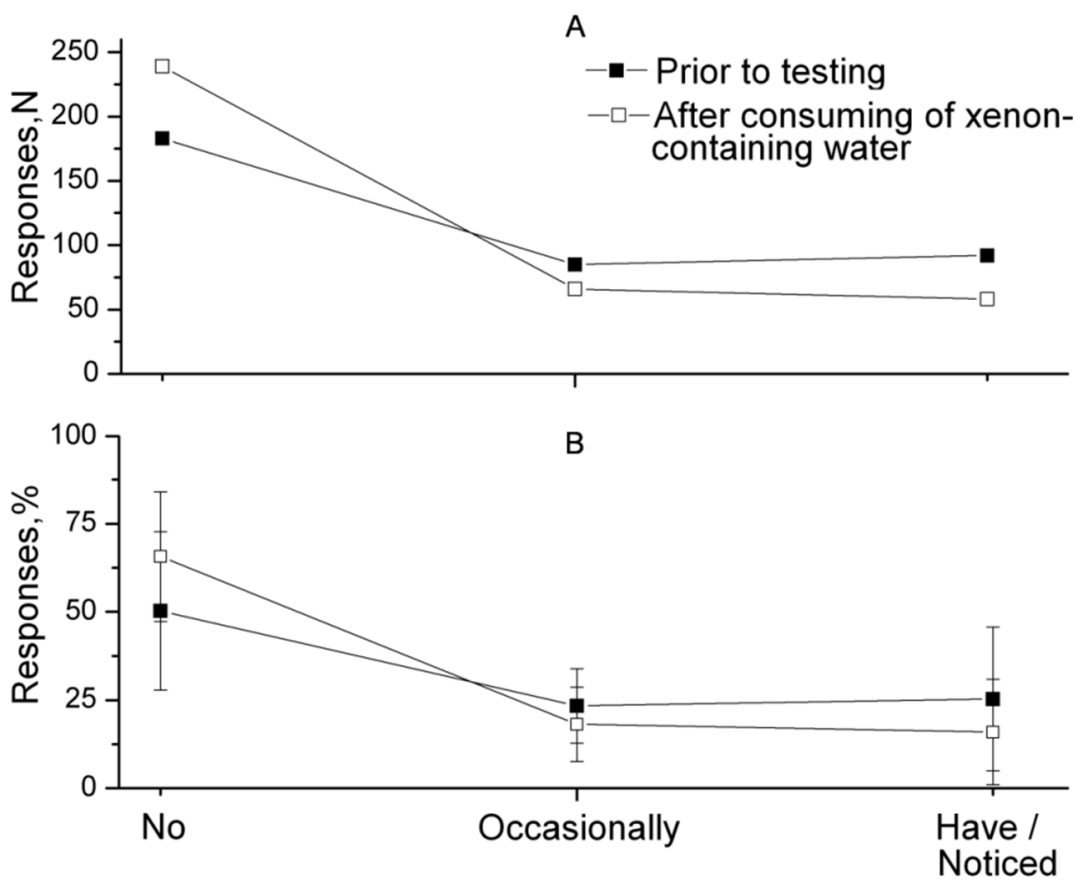

Figure 2. Effect of xenon-containing drinking water physiological indicators of all volunteers.

There is a decrease amount "disturbing" (92 to 58) and an increase of "positive" responses (from 183 to 239) (A, in absolute values) and, respectively, from $25 \%$ to $16 \%$ and from $50 \%$ to $65 \%$ (B as a percentage of all volunteers). Thus, when answering the question "Do you have headaches or dizziness?" answered "no" 9 volunteers of 26 (34.6\%) prior to testing and 18 of $26(65.4 \%)$ after 2 months of consuming xenon-containing water. Data are presented as Mean $\pm \mathrm{SD}$.

The results showed that regular use of drinking water with xenon has a positive effect on the general state of the organism, similar to the effects of inhalation of xenon use during therapeutic procedures. In studies with inhalation of xenon and nitrous oxide, conducted on men-volunteers, it has shown a positive sedative effect of xenon, a more pronounced compared with nitrous oxide [13].

\section{Conclusions}

Our results suggest a new, alternative method of administering xenon to the human body as part of the drinking water. Thus, we propose the use of drinking water with xenon as an additional procedure between xenon inhalation. This study is the first attempt to quantify the effect of xenon in the composition of drinking water on human psycho-emotional performance. In the future we plan to use advanced methods of questioning involving a large number of volunteers.

\section{Acknowledgment}

The paper was written as part of the research project No. 8.2.31.2015, carried out with the support of the Program "Research Foundation of Tomsk State University named after D.I. Mendeleev" in $2015-2016$. 


\section{References}

[1] B.D. Jordan, E.L. Wright, Xenon as an anesthetic agent., AANA J. 78, 387 (2010)

[2] B. Lachmann, S. Armbruster, W. Schairer, M. Landstra, A. Trouwborst, G.J. Van Daal, et al., The Lancet 335, 1413 (1990) doi: 10.1016/0140-6736(90)91444-F

[3] S.L.M. de Sousa, R. Dickinson, W.R. Lieb, N.P. Franks, Anesthesiology 92, 1055 (2000)

[4] P.-L. Chau, Br. J. Pharmacol 161288 (2010) doi:10.1111/j.14765381.2010.00891.x.

[5] T. Yamakura, R.A. Harris, Anesthesiology 93, 1095 (2000) doi:10.1097/00000542-200010000-00034

[6] R.D. Booker, A.K. Sum, Biochim. Biophys. Acta - Biomembr 1828, 1347 (2013) doi:10.1016/j.bbamem.2013.01.016

[7] R.S. Cantor, Biochemistry 36, 2339 (1997) doi:10.1021/bi9627323

[8] M. Weinrich, D.L. Worcester, J. Phys. Chem. B. 117, (2013) 16141 doi:10.1021/jp411261g

[9] E. Yamamoto, T. Akimoto, H. Shimizu, Y. Hirano, M. Yasui, K. Yasuoka, J. Phys. Chem. B. 116, 8989 (2012) doi:10.1021/jp303330c

[10] J.H. Lawrence, W.F. Loomis, C.A. Tobias, F.H. Turpin, J. Physiol. 105, 197 (1946)

doi: 10.1113/jphysiol.1946.sp004164

[11] L.M. Stimson, I. Vattulainen, T. Róg, M. Karttunen, Cell. Mol. Biol. Lett. 10, 563 (2005)

[12] N. V. Stryapko, T.G. Sazontova, V.I. Potievskaya, A.A. Khairullina, I.B. Vdovina, A.N. Kulikov, et al., Gen. Reanimatol 10, 50 (2014) doi:10.15360/1813-97792014-2-50-56

[13] A. Bedi, C. McCarroll, J.M. Murray, M.A. Stevenson, J.P.H. Fee, Anaesthesia. 57 , 233 (2002) doi:10.1046/j.0003-2409.2001.02455.x 